\title{
PROSPECTS FOR THE BIOLOGICAL CONTROL OF LANTANA CAMARA (VERBENACEAE) IN NEW ZEALAND
}

\author{
N.W. WAIPARA ${ }^{1}$, C.J.WINKS ${ }^{1}$, Q. PAYNTER ${ }^{1}$, N. RIDING ${ }^{2}$ \\ and M.D. DAY ${ }^{2}$ \\ ${ }^{1}$ Landcare Research, 231 Morrin Road, Private Bag 92170, Auckland, \\ New Zealand \\ ${ }^{2}$ Biosecurity Queensland, Department of Primary Industries and Fisheries, Alan \\ Fletcher Research Station, PO Box 36, Sherwood, Queensland 4075, Australia \\ Corresponding author: nick.waipara@arc.govt.nz.

\begin{abstract}
Lantana camara is an environmental weed in the northern North Island of New Zealand. It is an increasingly observed problem in forest margins, coastal scrublands, dunes, plantations and island habitats, and its rapid, uncontrolled growth can create dense impenetrable thickets, suppressing vegetation and bush regeneration. Biological control options are being considered for its management. A strain of the Brazilian rust Prospodium tuberculatum was released against lantana in Australia in 2001. This rust was screened against invasive forms of the weed that occur in New Zealand and was found to be pathogenic under glasshouse conditions. A survey found no evidence that the rust occurs in New Zealand. It is concluded that $P$. tuberculatum is potentially a suitable agent for the biocontrol of lantana in New Zealand and further research should be carried out prior to importation of the organism. Keywords: weed, rust, biotype, National Pest Plant Accord species.
\end{abstract}

\section{INTRODUCTION}

Lantana camara L. (Verbenaceae) is a major pantropical weed of both agricultural and natural ecosystems. In New Zealand, it is an environmental weed in the Northland, Auckland and Bay of Plenty regions and invades coastal scrublands, consolidated dunes, forest margins and plantations. It is regarded as a serious threat to island and coastal cliff habitats in particular and has been declared a National Pest Plant Accord species by Biosecurity New Zealand. The plant is a sprawling, woody, aromatic perennial shrub growing up to $3 \mathrm{~m}$ high, covered in sharp prickles, with clusters of yellow, pink, red or orange flowers. It is widely spread via bird-dispersed seeds, or locally, by suckering from shallow lateral roots (Roy et al. 2004). It forms dense impenetrable thickets, which suppress understory vegetation. Lantana thickets also restrict movement of stock and people, and the plant can poison stock (Day et al. 2003).

The weed occurs as a complex of artificially bred polyploids of mixed hybrid origins, the progenitors of which originated throughout the tropical and sub-tropical zones of the Americas. The species has been subject to intensive horticultural improvement for flower colour, including crossing with other Lantana species, resulting in a species complex (Ellison et al. 2006). In the latter half of the 1800s these 'cultivars' were distributed around the world, including Australia and New Zealand. The different genetic types of the lantana complex are referred to as 'forms' to cover all biotypes and varieties of the plant (Ellison et al. 2006).

Lantana has been a difficult weed to control by chemical and cultural methods. Biological control, while attempted worldwide, with a total of 41 different natural enemies having been released in 42 countries since 1902 (Day et al. 2003), has not been particularly successful (Zalucki et al. 2007). One of the obstacles in achieving 
successful control is that not all forms are attacked by all agents. Two insects, the tingid Teleonemia scrupulosa and the mirid Falconia intermedia, prefer the non-pink flowering forms, while an introduced fungal rust pathogen, Prospodium tuberculatum, attacks a minority of flowering forms in Australia (M.D. Day, Biosecurity Queensland, Australia, pers. comm.). Since its introduction into Australia from Brazil in 2001, the rust has established at over 40 sites along the east coast and has recently begun to spread beyond these sites (M.D. Day, unpubl. data). Prospodium tuberculatum primarily infects the leaves of lantana causing rapid senescence, then progressing to infect stems and petioles leading to significant dieback of branches (Thomas et al. 2006). Recent field observations in Australia, have found that plants with high levels of rust infection are beginning to show signs of defoliation (M.D. Day, pers. comm.).

In 2006, Auckland, Bay of Plenty and Northland Regional councils prioritised lantana as a target for biological control, and P. tuberculatum was selected as a potential candidate for introduction due to its establishment in Australia. Importing arthropods was not considered as these agents show only seasonal effects and it was considered that New Zealand may be too cool for them to have any substantial effect on lantana. This paper describes pathogenicity assays that were conducted to assess susceptibility of the two invasive forms of lantana in New Zealand (orange and pink flowered forms) to $P$. tuberculatum. Surveys of lantana in New Zealand were also conducted to ensure the rust had not autonomously arrived in New Zealand, as had the bridal creeper/smilax rust Puccinia myrsiphylli (Harman et al. 2008).

\section{MATERIALS AND METHODS \\ Infection of Prospodium tuberculatum on New Zealand plant material}

Cuttings of both the orange and pink-flowering forms of $L$. camara were collected from plants across the current naturalised geographical range of lantana in New Zealand (Table 1). Healthy sections, i.e. showing no signs of disease, were selected for excision, propagated for 8 weeks and sent to the Department of Primary Industries and Fisheries, Alan Fletcher Research Station in Queensland to assess their susceptibility to the introduced strain of $P$. tuberculatum (IMI383461).

Three healthy plants from four New Zealand field sites were inoculated, along with two susceptible Australian lantana plants (positive control) with a suspension of $0.3 \mathrm{~g}$ (wet weight) urediniospores in $300 \mathrm{ml}$ distilled water, via a $500 \mathrm{ml}$ squirt bottle on 4 May 2006. All pots were then placed within a sealed, plastic-covered cage, which was supplied with distilled water vapour from a Salton Humidifier set at high humidity and low-medium moisture for $24 \mathrm{~h}$ at a constant temperature of $21-23^{\circ} \mathrm{C}$ in the glasshouse, resulting in $21-24^{\circ} \mathrm{C}$ within the cage. Plants were maintained in the glasshouse for 3 weeks until sporulation had occurred on the positive controls. Symptoms of disease were then assessed in all plants, including the Australian lantana control plants. After 3 weeks, plants were considered susceptible if they had developed pustules (positive) or not susceptible if no symptoms had appeared (negative). This assessment was based on the standardised methods of assessment of the symptoms described previously (Ellison et al. 2006; Thomas et al. 2006). Infection is determined by scoring the presence of mature pustules, generally evident by day 21 , and mainly visible on the lower leaf surface (Ellison et al. 2006). Scores are assigned as follows: $0=$ no macroscopically visible symptoms; $0 \%$ leaf area with pustules; $1=$ low sporulation with sparse urediniospore production; $>25 \%$ leaf area with pustules; $2=$ moderate sporulation and urediniospore production; $50-75 \%$ leaf area with pustules, $3=$ abundant sporulation with copious urediniospore production leading to defoliation; $>75 \%$ leaf area with pustules. These standardised methods also previously demonstrated no treatment effect on all uninoculated negative control plants (Thomas et al. 2006; Ellison et al 2006); this treatment was therefore not repeated when assessing these New Zealand plants. 
TABLE 1: Number of plants sampled for testing in Australia of susceptibility to Prospodium tuberculatum and number of plants surveyed for disease on L. camara at 11 field sites across three regions in 2007 and 2008.

\begin{tabular}{|c|c|c|c|c|c|}
\hline Region & Sites & Form & $\begin{array}{c}\text { P. tuberculatum } \\
\text { testing }^{1}\end{array}$ & $\begin{array}{c}2007 \\
\text { survey }\end{array}$ & $\begin{array}{l}2008 \\
\text { survey }\end{array}$ \\
\hline \multirow[t]{6}{*}{ Auckland } & Eastern Beach & Pink & & 2 & 2 \\
\hline & Maraetai & Orange & & 3 & 3 \\
\hline & Mission Bay & Pink & & 1 & 2 \\
\hline & Muriwai & Pink & & - & 2 \\
\hline & Newmarket ${ }^{2}$ & Pink & 3 & 3 & - \\
\hline & Waiheke Island & Orange/Pink & & 1 & 7 \\
\hline \multirow[t]{3}{*}{ Bay of Plenty } & Katikati & Orange & & - & 3 \\
\hline & Tauranga $^{3}$ & Orange & 3 & 5 & 1 \\
\hline & Waihi & Orange & & & 1 \\
\hline \multirow[t]{2}{*}{ Northland } & Rawene & Pink & 3 & 6 & 1 \\
\hline & Whangaroa & Pink & 3 & 5 & 1 \\
\hline
\end{tabular}

${ }^{1}$ Number of plants sampled ( 3 cuttings per plant) for propagation and testing in Australia.

${ }^{2}$ Two sites in Newmarket area were sampled in 2007, but only 1 site remained in 2008.

${ }^{3}$ Three sites in Tauranga area were sampled in 2007, but due to site clearances a different site was surveyed in 2008 .

\section{Survey of foliar pathogens on Lantana in New Zealand}

Eleven sites, comprising Auckland (6 sites), Bay of Plenty (3 sites) and Northland (2 sites), were surveyed over two growing seasons, 2006-2007 and 2007-2008 (Table 1). Surveys were undertaken between November and February in both years. At each site, plants were inspected for signs of pathogen damage. Any diseased leaves were collected for processing. A dissecting microscope was used to search necrotic areas for sporulation of $P$. tuberculatum and other pathogens. Methods outlined previously (Waipara et al. 2007) were used to isolate other pathogenic fungi from diseased tissues. Small pieces of tissue were cut from the leading edge of diseased areas, surface sterilised in $2 \%$ sodium hypochlorite for $1 \mathrm{~min}$ and plated onto potato dextrose agar (Difco Labs, Detroit, MI, USA) amended with $0.02 \%$ streptomycin (Sigma, St Louis, MI, USA). Plates were incubated under near-ultraviolet and white light at $18^{\circ} \mathrm{C}$. Microcolonies that were initiated from tissue fragments were sub-cultured for further identification.

\section{RESULTS}

\section{Infection of Prospodium tuberculatum on New Zealand plant material}

Both the orange and pink flowering forms from New Zealand were observed to be susceptible to infection by $P$. tuberculatum. The level of infection was assessed as moderate (score of 2, based on area of pustule development on symptomatic leaves) across all cuttings within 3 weeks of inoculation. Visual examination of leaves found pustules developing and sporulation on all the inoculated plants except for one of the Australian positive control plants, which had no visible symptoms.

\section{Survey of foliar pathogens on Lantana in New Zealand}

A very low level of disease was observed on all plants sampled across all sites and neither $P$. tuberculatum nor any other rust species was observed on lantana. Disease symptoms in the field were primarily minor leaf spots that would not be sufficient to impact severely on the aggressive vegetative growth or flower/fruit/seed production of the weed (Broughton 2000). Nine fungal species were identified from diseased leaves, of which the most commonly isolated were Colletotrichum gloeosporioides, Phoma exigua 
and a species of Phomopsis (Table 2). Another pathogen, Botryosphaeria parva, was associated with severely damaged shoots (dieback), but was recorded only from one plant at one highly disturbed roadside wasteland site near Maraetai, Auckland. The remainder of isolates (listed in Table 2), were encountered only sporadically and are regarded as secondary pathogens or saprophytes. All nine species are cosmopolitan and widespread in New Zealand (Pennycook 1989) and often infect hosts only after damage, insect feeding or environmental stress, and therefore are unlikely to be sufficiently virulent and/or host specific to be useful as biocontrol agents. Representative isolates were deposited into long term storage at Landcare Research, Auckland.

TABLE 2: Pathogens and other fungi and their associated symptoms found on L. camara in three regions of New Zealand. Values are the number of symptomatic plants infected by each pathogen, the number of isolates confirmed by plating and the number of isolates observed sporulating using light microscopy.

\begin{tabular}{|c|c|c|c|c|c|}
\hline \multirow[b]{2}{*}{ Pathogen } & \multirow[b]{2}{*}{ Symptoms } & \multirow[b]{2}{*}{ Region $^{1}$} & \multirow{2}{*}{$\begin{array}{l}\text { No. of } \\
\text { Plants }\end{array}$} & \multicolumn{2}{|c|}{ No. isolates from: } \\
\hline & & & & Plating & Microscopy \\
\hline Alternaria alternata & leaf spot & 2 & 8 & 4 & 8 \\
\hline Botrytis cinerea & $\begin{array}{c}\text { leaf and fruit } \\
\text { lesions }\end{array}$ & 2,3 & 7 & 3 & 13 \\
\hline Botryosphaeria parva & $\begin{array}{l}\text { leaf, stem, } \\
\text { shoot tip } \\
\text { dieback }\end{array}$ & 2 & 1 & 4 & - \\
\hline $\begin{array}{l}\text { Colletotrichum } \\
\text { gloeosporioides }\end{array}$ & leaf spot & $1,2,3$ & 9 & 6 & 7 \\
\hline Fusarium avenaceum & leaf spot & 3 & 1 & 5 & - \\
\hline Fusarium lateritium & leaf chlorosis & 2 & 1 & 3 & - \\
\hline Pestalotiopsis sp. & leaf spot & 1,3 & 2 & 2 & - \\
\hline Phoma exigua & leaf spot & $1,2,3$ & 11 & 17 & 1 \\
\hline Phomopsis sp. & leaf spot & 1,2 & 7 & 13 & - \\
\hline
\end{tabular}

${ }^{1}$ Key to region: $1=$ Northland, 2=Auckland, $3=$ Bay of Plenty.

\section{DISCUSSION}

Prospodium tuberculatum was not found at any site in New Zealand. The survey focused on the potentially susceptible forms of New Zealand L. camara, using a similar approach to Harman et al. (2008) who reported the first record of Puccinia myrsiphylli, a pathogen of the weed bridal creeper (Asparagus asparagoides) in New Zealand. Because of the monospecific nature of $P$. tuberculatum, searching for symptomatic $L$. camara is the method most likely to detect the pathogen, and other methods, such as spore trapping would not be appropriate.

No specialist pathogens were found in New Zealand on either orange or pink flowering plants of L. camara. Any damage that could be attributed to plant pathogens was very minimal and did not appear to usefully reduce vegetative growth or reproduction of the weed. No significant invertebrate herbivory was observed (C.J. Winks, unpubl. data).

The bioassay clearly demonstrated that the invasive New Zealand flowering forms tested were susceptible to infection by $P$. tuberculatum. Because of the very narrow intraspecficic host range (as discussed below), the experiment was designed to determine whether or not the pathogen would infect New Zealand L. camara, and was therefore terminated at 21 days once the score of 2 , indicating moderate infection, was reached. 
Despite the good infection levels observed on New Zealand lantana, the unexpected noninfection of one Australian positive control plant, along with the absence of a negative control treatment, requires the assay to be repeated to validate these results. A detailed study of the genetic variability of $L$. camara in relation to $P$. tuberculatum infection was beyond the scope of this study. Future work should investigate the severity of infection on New Zealand L. camara, including an analysis of the time course of infection, pustule development, and effects on defoliation and dry matter production. It will be important to investigate these effects under field conditions as well as in the laboratory.

Prospodium tuberculatum can often cause severe defoliation that visibly constrains the plant in its native range (Barreto et al. 1995). Host-range testing by Thomas et al. (2006), together with field surveys conducted in the native range (Barreto et al. 1995), clearly demonstrated that $P$. tuberculatum is a highly coevolved pathogen to the extent that it is only pathogenic to certain forms of L. camara. In Australia, it attacks only the pink-flowering forms, with some pink-flowering forms (from north Queensland) being resistant. In contrast, both invasive forms (pink and orange) of lantana in New Zealand were susceptible to infection by the Australian biocontrol biotype of P. tuberculatum. Given that lantana is of hybrid nature and the origins of the different hybrids are unknown (Ellison et al. 2006; Zalucki et al. 2007), it is not surprising that different lantana forms may vary in susceptibility to the rust in different countries.

The risk of non-target attack has been thoroughly assessed by Thomas et al. (2006), using the internationally accepted centrifugal phylogenetic system to help delineate the host-range of P. tuberculatum (Wapshere 1974; Briese \& Walker 2002). Fifty-two closely related, non-target plant species were screened for susceptibility to the rust. Most species were from the Verbenaceae and Lamiaceae families, but also included the Bignoniaceae, Pedaliaceae and Scrophulariaceae as well as more distantly-related plants from the order Solanales and Boraginaceae. None of these species, including the two other exotic genera of the Verbenaceae present in New Zealand, Phyla nodiflora and Verbena bonariensis, were found to be susceptible (Thomas et al. 2006). Thomas et al. (2006) also tested $P$. tuberculatum against 40 varieties of L. camara, but found only 15 forms were susceptible. In summary, previous host testing has shown the rust to have a very narrow intraspecific host range, and therefore presents little risk of infection to non-target species in New Zealand.

Recent field observations found that the rust is spreading within Australia, particularly in areas with high rainfall where defoliation of plants by the rust also appears to be more prevalent (M.D. Day, unpubl. data). Assessment of its efficacy as a biocontrol agent in Australia is ongoing.

The high degree of specificity of, and damage from $P$. tuberculatum, suggests it is a potentially useful classical biocontrol agent against lantana in New Zealand. Since the pathogens currently in New Zealand do little damage to lantana and because $P$. tuberculatum has not been observed here but can infect both invasive forms, the introduction of the rust from Australia could be recommended. However, it is suggested that prior to release of the biocontrol agent, further P. tuberculatum testing is undertaken to confirm the susceptibility of the New Zealand forms of L. camara to the selected strain.

\section{ACKNOWLEDGEMENTS}

The authors would like to thank Northland and Auckland Regional Councils for funding this project.

\section{REFERENCES}

Barreto RW, Evans HC, Ellison CA 1995. The mycobiota of the weed Lantana camara in Brazil, with particular reference to biological control. Mycological Research 99: 769-782.

Briese DT, Walker A 2002. A new perspective on the selection of test plants for evaluating the host-specificity of weed biological control agents: the case of Deuterocampta 
quadrijuga, a potential insect control agent of Heliotropium amplexicaule. Biological Control 25: 273-287.

Broughton S 2000. Review and evaluation of lantana biocontrol programs. Biological Control 17: 272-286.

Day MD, Wiley CJ, Playford J, Zalucki MP 2003. Lantana: Current Management Status and Future Prospects. ACIAR Monograph series 102, Canberra. 128 p.

Ellison CA, Pereira JM, Thomas SE, Barreto RW, Evans HC 2006. Studies on the rust Prospodium tuberculatum, a new classical biological control agent released against the invasive alien weed Lantana camara in Australia. I. Life-cycle and infection parameters. Australasian Plant Pathology 35: 309-319.

Harman HM, Waipara NW, Winks CJ, Smith LA, Peterson PG, Wilkie JP 2008. Natural enemies of bridal creeper, Asparagus asparagoides, in New Zealand. New Zealand Plant Protection 61: 362-367.

Pennycook SR 1989. Plant diseases recorded in New Zealand. Volume 1-3. Plant Diseases Division, DSIR, Auckland, New Zealand.

Roy B, Popay I, Champion P, James T, Rahman A 2004. An illustrated guide to common weeds of New Zealand. Second Edition. New Zealand Plant Protection Society, Lincoln, New Zealand. 314 p.

Thomas SE, Ellison CA, Tomley B 2006. Studies on the rust Prospodium tuberculatum, a new classical biological control agent released against the invasive alien weed Lantana camara in Australia. 2. Host range. Australasian Plant Pathology 35: 321-328.

Waipara NW, Winks CJ, Smith LA, Wilkie JP 2007. Natural enemies of Japanese honeysuckle, Lonicera japonica, in New Zealand. New Zealand Plant Protection 60: 158-163.

Wapshere AJ 1974. A strategy for evaluating the safety of organisms for biological weed control. Annals of Applied Biology 77: 201-211.

Zalucki MP, Day MD, Playford J 2007. Will biological control of Lantana camara ever succeed? Patterns, processes and prospects. Biological Control 42: 251-261. 